\title{
A Study on the pattern of usage of library facilities at the Medical Library, University of Peradeniya
}

\author{
P.A.S.H. PERERA*
Senior Assistant Librarian
University of Peradeniya \\ Medical Library \\ Peradeniya, Sri Lanka
}

BSc, MPhil (Peradeniya), MA(London),Pg. Dip(London)

\section{Abstract}

\begin{abstract}
A survey was carried out at the Medical Library of the University of Peradeniya to evaluate the services and the usage of library materials available within the library. The methodology consisted of survey research and analysis of library statistics taken during a selected period. A questionnaire designed with some targeted objectives was used as an instrument in the survey along with other tools such as various registers to count the number of users and also the purpose of their visit to the library. Responses received from the survey were turned into data that could be analyzed using standard methods. Results revealed significant variation within and among user groups, concerning various aspects of the study.
\end{abstract}

\section{Introduction}

Fulfilling user needs is an important aspect of library management. Regular evaluation of user needs against existing services and the library collection is a necessary management technique for the continuous upgrading of the services provided by the library of any kind. The management staff of a library should be aware of the current requirements of their clients/users. User needs vary from one

- Present Address: Research Fellow, The Library, University of Brunei Darussalam, Brunei Darussalam 
library to another as well as from time to time. Therefore, carrying out regular surveys on user needs at any given time, in various aspects of library usage is an invaluable guide in determining the future directions of library development. Further it is a means of evaluating the existing collection development policy of the library in order to make a judgment, whether the available resources are efficiently directed to achieve user satisfaction

The medical library serves for the two faculties Medicine and Dental Sciences of the university, hence houses the collection of books and periodicals pertaining to medical and dental sciences. Its readership includes undergraduates, postgraduates and academic staff of the two faculties, doctors and consultants of all the teaching hospitals of the faculty of Medicine. The number of registered members of the library is around 2000. The collection of the library contains about 19000 books and periodicals in total of 1200 titles. The library is being extensively used specially by the undergraduates, therefore it observes long library hours from 7.30 a.m. -8.00 p.m. everyday through out the year except for special public holidays.

The objective of the study was to investigate the appropriateness of the collection of library materials on the information needs of the users, as well as the extent of use of the collection and the facilities available within and outside through the medical library. The survey concentrated mainly on the pattern of usage of available library materials / facilities at present by the users. Such a study should provide us with sufficient data and information to evaluate the state/quality of the existing system, to explain and to give justification for changes, improvement, expansion or delimitation in areas such as services, staff and user education. It further enables us to make a judgment as to whether or not our limited funds and resources are being utilized properly.

Prior to this study, user input to the library was generally informal and unsolicited through such channels as suggestion books, anecdotal comments at the service counters, comments received through faculty library committee meetings, faculty board meetings, senate or council meetings and through faculty liaisons on libraryrelated issues. The catalyst for the development of the present survey came with the realization of change in the user expectation in the new information era.

\section{User surveys}

Library user surveys have become widespread in academic libraries during the past two decades. Surveys have often been used as a method to assess service quality and user satisfaction. Literature on user surveys reports, studies and reviews from library professionals and educators such as Hernon and McClure(1990); Van House, Well and McClure(1990); Hernon and Altman(1998,2000), and Hernon and 
Whitman(2001) among many others. According to these studies, user surveys cari be designed and administered in a number of ways. Surveys are administered in a selected study population and responses receive from the respondents are then turned into data that can be analyzed. Surveys can range from broad and comprehensive to those narrowly focused on specific services or activities (Hiller,2001).When properly designed and administered, user surveys can provide both qualitative and quantitative data directly from the target population.

\section{Survey methodology and design of the medical library}

A literature survey on studies and methodologies on evaluation of usage of libraries, in academic libraries of diverse origin which included both modern, developed libraries and moderately developed libraries was carried out and compared before deciding upon a methodology to be adopted for the present study. Consequently, a survey method that would provide following information was designed for the study.

- who uses the library more

- how and why the library was used

- to what extent the facilities were used

- what sources were used most

- suggestions for improvements

- overall how satisfied the users are

The methodology that was designed, consists of two parts ; careful and continuous checking on various types of library statistics, and use of a questionnaire as an instrument to collect information from users. The various categories of users, who would be sample subjects, the range of information sources and the facilities available within the framework of the medical library on which the study was based upon, were identified.

In the first part of the study, the period of six months from January to June 2004 was selected to carry out the study on the pattern of usage of library materials by keeping appropriate library statistics. Any user of the library during this period was taken as a sample subject of the study in this survey. Statistics were maintained approaching a subject analysis as well as an analysis of the type of materials. For this purpose a count on the library materials used by the readers (all kinds) during the course of the day through the service counter was taken and recorded in the subject order, during the specified period. Different types of materials were counted separately and recorded accordingly. To have a track of the photocopy-statistics, library materials those were photocopied inside the library by the readers were kept on record in a separate register, indicating the type of the material and the subject covered by it. In order to evaluate the purpose of visits to the library of each user, 
the number of readers entering the library was counted each time they visited the library by marking their presence in a register by the reader himself/herself. Reader was assigned to tick off in columns indicating the purpose of the visit and the time. This exercise was carried out during a period of two weeks $1^{\text {st }}-15^{\text {th }}$ February 2004.

In the second part of the study, a questionnaire was designed to collect data that could be used to evaluate overall affairs of the library. Survey questions were similar for all the categories of user samples. There was a core group of questions that dealt with:

$\begin{array}{ll}\text { - } & \text { information sources needed } \\ \text { - } & \text { reasons and frequency of library use } \\ \text { - } & \text { library collection } \\ \text { - } & \text { importance of library materials } \\ \text { - } & \text { fulfilling objectives of the library visits } \\ \text { - } & \text { reasons for not fulfilling the objectives } \\ \text { - } & \text { rating on the importance of different collections } \\ \text { - } & \text { opinion about the library staff } \\ & \text { ovysical arrangement }\end{array}$

Study population consisted of 1530 undergraduates, 180 academic staff members and 15 postgraduates. A sample of 1050 medical undergraduates, 225 dental undergraduates, all the academic staff and all the postgraduates were used for the study, excluding the most junior batches of students of the two faculties due to the short period of their use of library facilities. Short-time users and members of the extended faculty were also excluded from the study due to the same reason. Questionnaires were administered to the students of $2^{\text {nd }}-5^{\text {th }}$ year batches of both faculties, during their practical class or just before a lecture, so that it could be collected back at the end of the class. Aim was to get the $100 \%$ response from the respondents. Questionnaires for the academic staff were sent through internal delivery while it was handed over personally to postgraduate students.

\section{Survey response and survey results}

\subsection{Evaluation on Issues of library materials}

During the six-month period from January-June 2004 that was selected for the study, at the end of each day, issue slips / issue tickets were arranged according to the subject order (class number) of the item issued. The number of issues in each 
major subject was counted and marked on a data sheet. Lending issues and reference issues were counted separately for each month. This data was used to produce the Tables 4.1.1 and 4.1.2, and Charts 4.1.1 and 4.1.2 as shown below.

\section{Table 4.1.1 Lending issues}

$\begin{array}{lcccccc}\text { Subject area } & \text { Jan } & \text { Feb } & \text { Mar } & \text { Apr } & \text { May } & \text { Jun } \\ \text { Statistics } & 28 & 36 & 33 & 25 & 36 & 36 \\ \text { Forensic medicine } & 61 & 69 & 72 & 102 & 127 & 248 \\ \text { Biochemistry } & 86 & 102 & 96 & 85 & 133 & 219 \\ \text { Anatomy } & 101 & 145 & 130 & 113 & 124 & 284 \\ \text { Physiology } & 80 & 108 & 102 & 95 & 149 & 290 \\ \text { Nutrition } & 13 & 19 & 22 & 18 & 149 & 90 \\ \text { Disease prevention } & 15 & 23 & 25 & 24 & 29 & 76 \\ \text { Pharmacology } & 133 & 160 & 165 & 188 & 293 & 344 \\ \text { Clinical medicine } & 116 & 128 & 130 & 140 & 227 & 298 \\ \text { Microbiology } & 82 & 191 & 161 & 177 & 164 & 297 \\ \text { Pathology } & 104 & 179 & 180 & 192 & 233 & 347 \\ \text { Diseases } & 43 & 82 & 78 & 88 & 114 & 115 \\ \text { Psychiatry } & 17 & 31 & 33 & 39 & 60 & 60 \\ \text { Infectious diseases } & 49 & 65 & 53 & 57 & 137 & 118 \\ \text { Surgery } & 55 & 126 & 120 & 152 & 176 & 195 \\ \text { Dentistry } & 71 & 114 & 155 & 172 & 237 & 283 \\ \text { Ophthalmology } & 35 & 25 & 83 & 92 & 85 & 70 \\ \text { Gynecology - } & & & & & & \\ \text { Obstetrics } & 98 & 153 & 140 & 147 & 213 & 248 \\ \text { Pediatrics } & 32 & 84 & 75 & 90 & 111 & 148\end{array}$




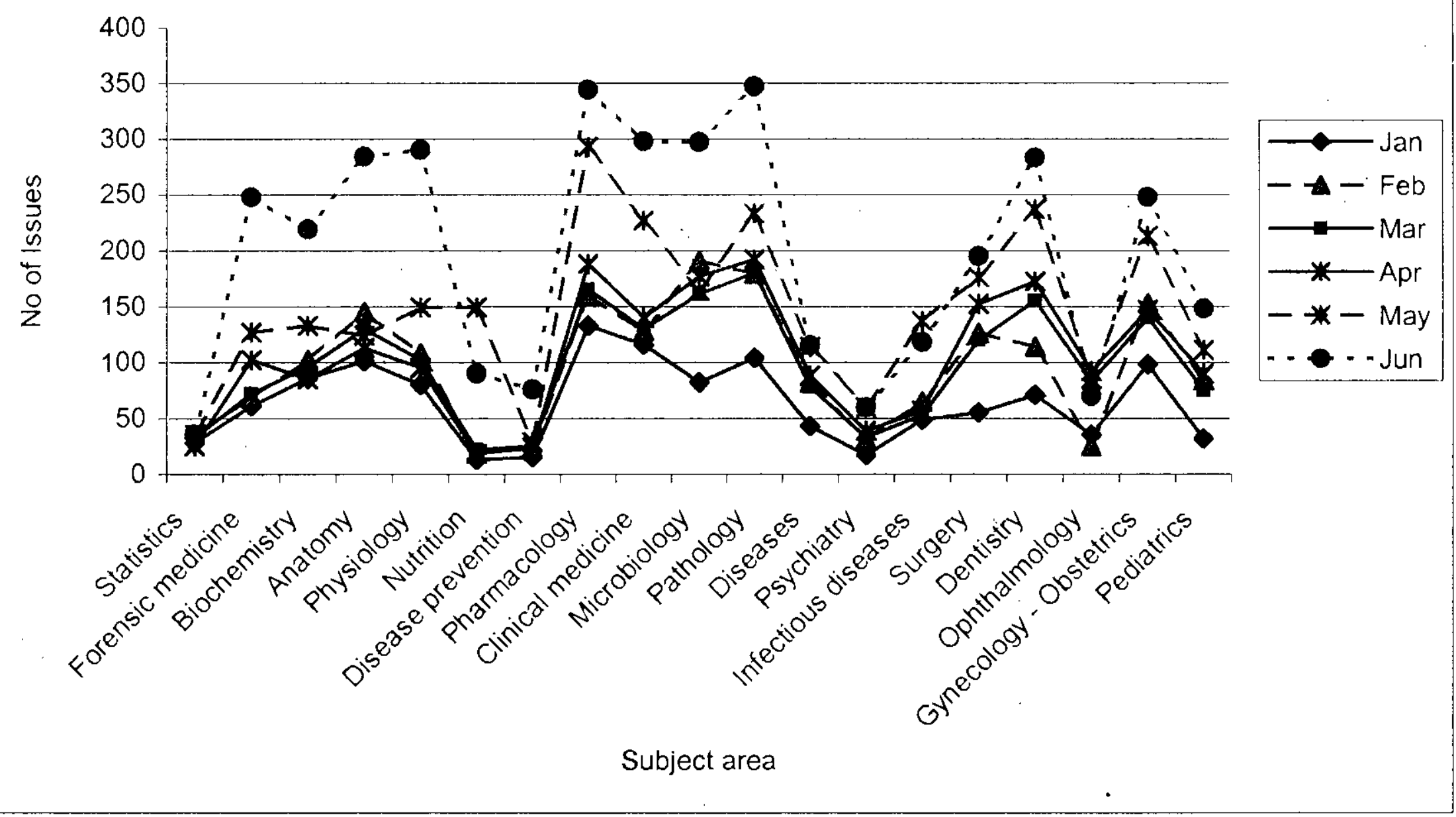

\section{Chart 4.1.1}


Table 4.1.2 Reference issues

$\begin{array}{lcccccc}\text { Subject area } & \text { Jan } & \text { Feb } & \text { Mar } & \text { Apr } & \text { May } & \text { Jun } \\ \text { Statistics } & 111 & 178 & 106 & 28 & 53 & 69 \\ \text { Forensic medicine } & 360 & 252 & 276 & 247 & 351 & 862 \\ \text { Biochemistry } & 475 & 510 & 386 & 285 & 289 & 458 \\ \text { Anatomy } & 788 & 867 & 711 & 510 & 689 & 796 \\ \text { Physiology } & 447 & 468 & 351 & 229 & 329 & 531 \\ \text { Nutrition } & 50 & 50 & 62 & 81 & 392 & 176 \\ \text { Disease prevention } & 23 & 27 & 29 & 30 & 55 & 130 \\ \text { Pharmacology } & 446 & 367 & 592 & 864 & 1359 & 1052 \\ \text { Clinical medicine } & 434 & 587 & 446 & 322 & 448 & 743 \\ \text { Microbiology } & 755 & 1024 & 767 & 455 & 1193 & 1203 \\ \text { Pathology } & 574 & 811 & 681 & 664 & 1274 & 1145 \\ \text { Diseases } & 474 & 535 & 480 & 391 & 605 & 674 \\ \text { Psychiatry } & 128 & 237 & 136 & 73 & 203 & 124 \\ \text { Infectious diseases } & 490 & 702 & 451 & 202 & 770 & 1061 \\ \text { Surgery } & 375 & 447 & 362 & 238 & 383 & 373 \\ \text { Dentistry } & 487 & 549 & 535 & 585 & 746 & 1023 \\ \text { Ophthalmology } & 270 & 254 & 628 & 1210 & 311 & 237 \\ \text { Gynecology- } & & & & & & \\ \text { Obstetrics } & 464 & 354 & 323 & 263 & 401 & 425 \\ & & & & & & \\ \text { Pediatrics } & 506 & 447 & 368 & 210 & 266 & 268\end{array}$


Reference Issues Jan-Jun

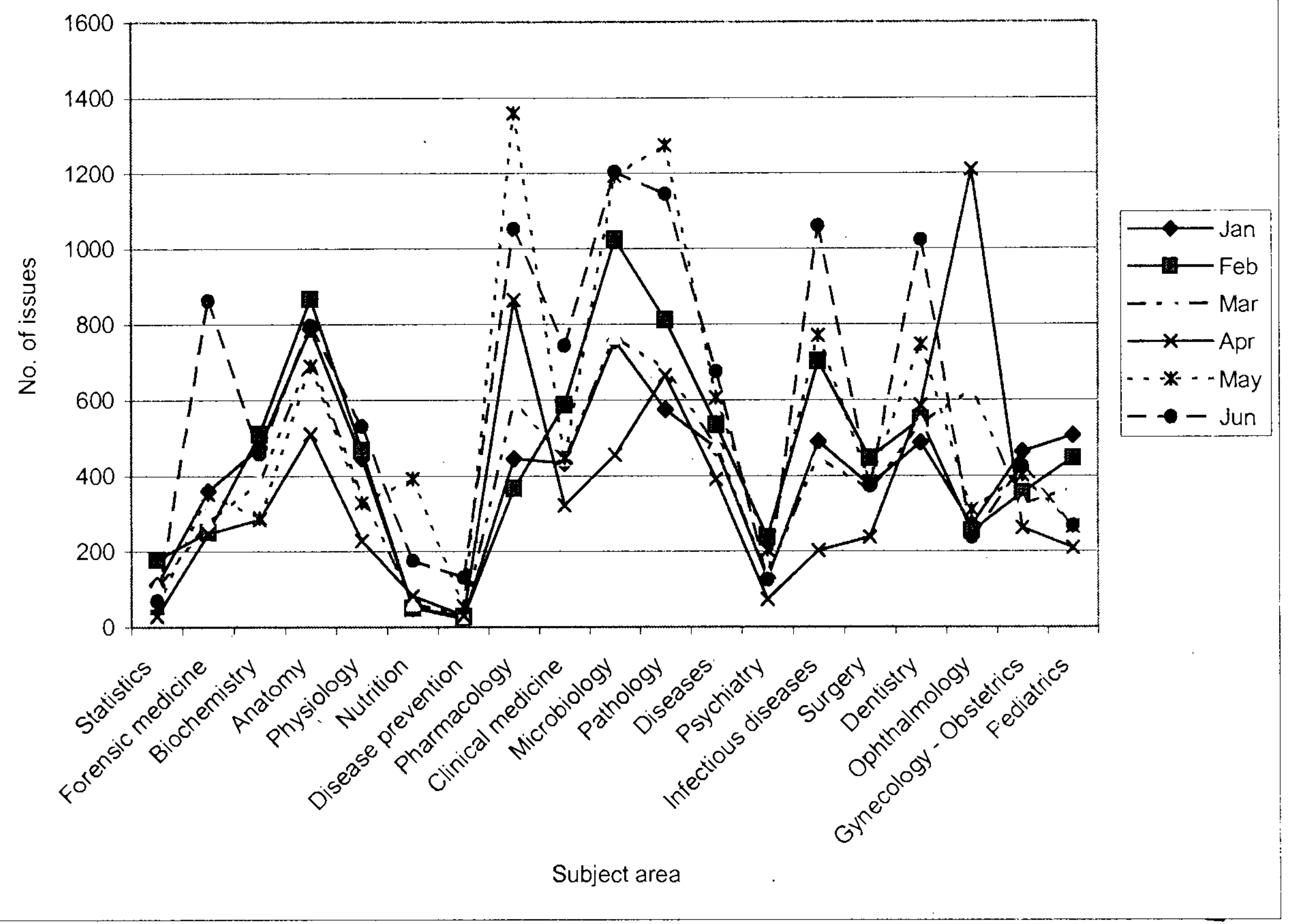

\section{Chart 4.1.2}


The pattern of usage of books by subject is shown in Charts $4 \cdot 1 \cdot 1-4.1 .2$. The results are further summarized in the Table 4.1.3., for reference issues.

Legend for table 4.1.3:
A Forensic medicine
I Microbiology
Q Gynecology
$B$ Biochemistry
$J$ Pathology
$R$ Pediatrics
C Anatomy
$\mathrm{K}$ Diseases
D Physiology
L Psychiatry
E Nutrition
$M$ Infectious diseases
$F$ Diseases prevention
$N$ Surgery
$G$ Pharmacology
O Dentistry
$\mathrm{H}$ Clinical medicine
P Ophthalmology

1-6 Order of number of library materials issued during Jan.-June ;

1-highest number of issues and, 6-sixth highest number of issues.

$\begin{array}{ccccccc}\text { Month } & \mathbf{1} & \mathbf{2} & \mathbf{3} & \mathbf{4} & \mathbf{5} & \mathbf{6} \\ \text { January } & \mathrm{C} & \mathrm{I} & \mathrm{J} & \mathrm{R} & \mathrm{M} & \mathrm{O} \\ \text { February } & \mathrm{I} & \mathrm{C} & \mathrm{J} & \mathrm{M} & \mathrm{H} & \mathrm{O} \\ \text { March } & \mathrm{I} & \mathrm{C} & \mathrm{J} & \mathrm{P} & \mathrm{G} & \mathrm{O} \\ \text { April } & \mathrm{P} & \mathrm{G} & \mathrm{J} & \mathrm{O} & \mathrm{C} & \mathrm{I} \\ \text { May } & \mathrm{G} & \mathrm{J} & \mathrm{I} & \mathrm{M} & \mathrm{O} & \mathrm{C} \\ \text { June } & \mathrm{I} & \mathrm{J} & \mathrm{M} & \mathrm{G} & \mathrm{O} & \mathrm{B}\end{array}$

Table 4.1.3

Table 4.1.3 shows that subject of the library materials issued varies from time to time.

A significant usage of library material in Anatomy, Pathology, Microbiology, and Pharmacology is shown during the period. Therefore it suggests that more materials are needed in the library in these subjects. Library materials in Infectious diseases and Dentistry also have been heavily used, as such; there have been a considerable demand for materials in these subjects. Tables 4.1.1-4.1.2 show the other subject areas in which the library materials have been in constant circulation during the period January-June 2004.

\subsection{Evaluation on the purpose of visit to the library by readers}

Readers were categorized into four groups; namely academic staff, undergraduates, postgraduates and others. Data collected were used to determine the average 
number of readers per day and to evaluate the purpose of these readers' visits to the library as a percentage of the total number of readers visited during the selected time period.

Data reveals that the average number of readers per day had been 179 during this period. Out of the total number of readers 2511 visited the library during the two weeks, $97 \%$ were undergraduates, $1.3 \%$ were academic staff, $1.3 \%$ were postgraduates and $1.4 \%$ has been in other categories such as, casual visitors from other hospitals in Kandy and other peripheral areas, health professionals from other sectors and students of other research and academic institutions.

The purpose of the visit to the library of these 2511 readers had been as follows: $15 \%$ to return borrowed books, $10 \%$ to look for a book, $33 \%$ were to read their notes, $45 \%$ to do the reference work, $18 \%$ to borrow books, $5 \%$ has been to photocopy library materials, only $1 \%$ of the readers have visited to use journals, another $1 \%$ to carryout CD-ROM searches, $1 \%$ to meet a person and $3 \%$ to use the discussion room facility.

The same set of data was used to evaluate the time the reader used the library. Data reveals that $80.2 \%$ of the readers have used the library during the daytime (7.30a.m-4.00p.m.) and $19.8 \%$ have visited the library in the evening between 6.00 J.m.- 8.00 p.m.

This study shows a significant variation in the purpose of the visit to the library. It reveals that the library facilities were used mainly $(97 \%)$ by the undergraduates and the purpose of the use has been mainly for reference work and next for reading their notes. To borrow books and return books have been the next important purpose of the library use, by the readers. Almost half of the user population using the library for reference work infers that the library materials are being used to a great extent. It further reveals that to a certain degree, the library has been used as a place to study; by $33 \%$ of the users.

\subsection{Evaluation on the photocopying service}

Daily photocopying statistics were taken separately in both categories users and subjects, to determine the number of photocopies taken by various user categories and in each subject/type of material. This data was used to produce the following Charts 4.3.1 and Chart 4.3.2. 


\section{Photocopying - Readers}

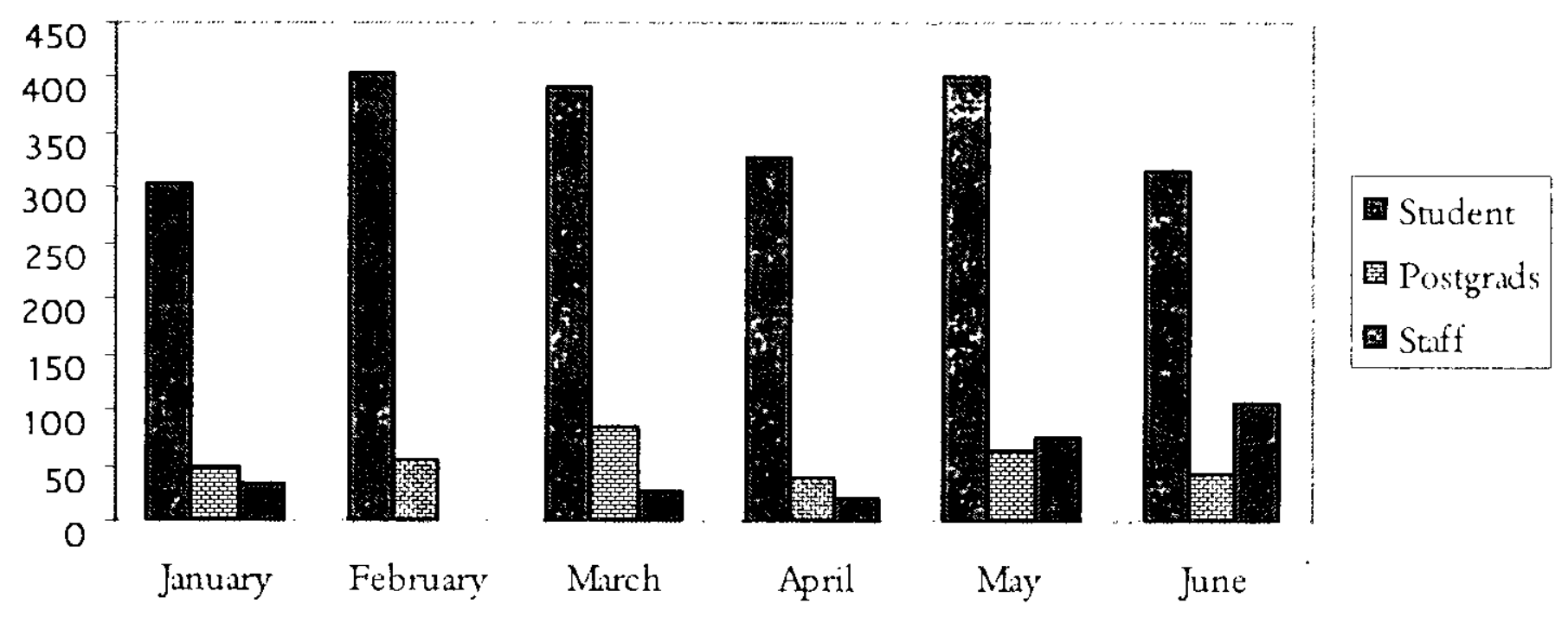

Chart 4.3.1

Photocopying - subject / type

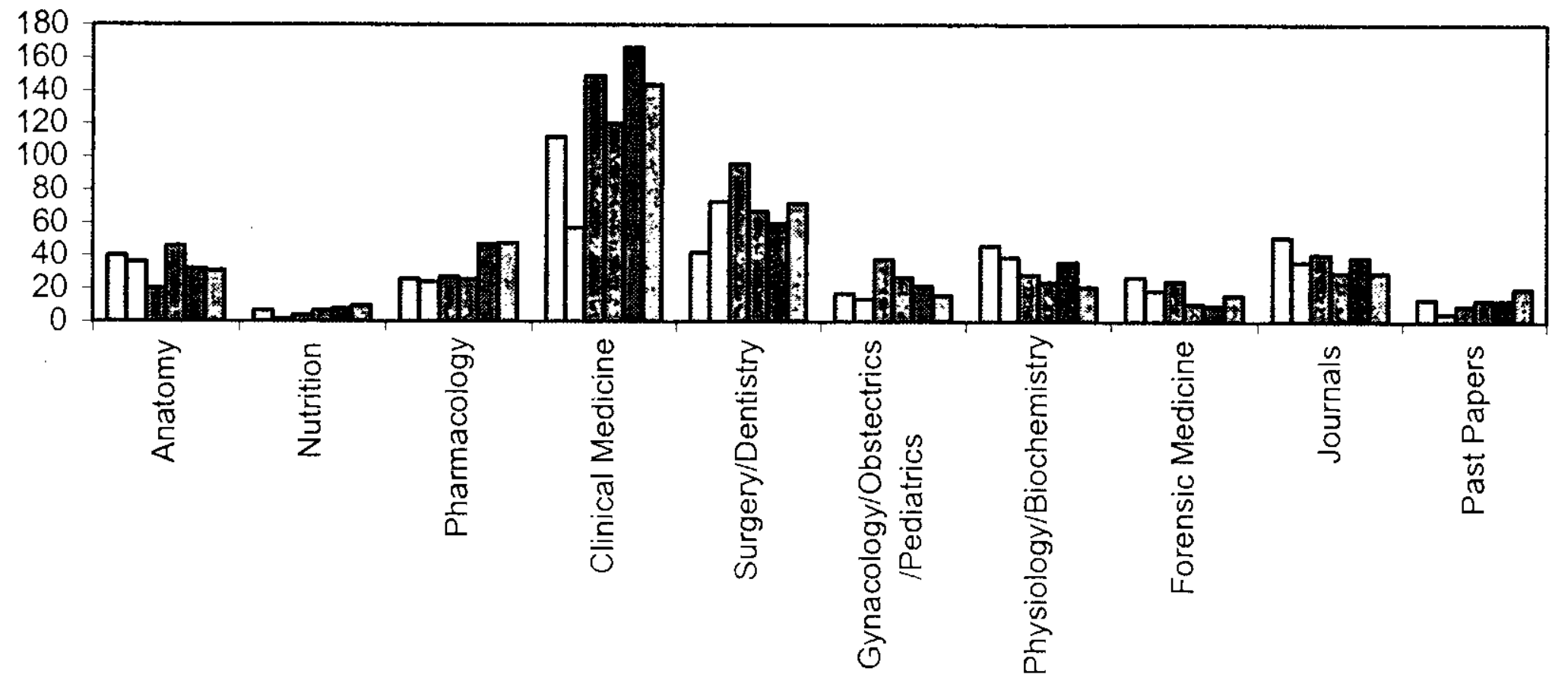

\begin{tabular}{|l}
\hline January \\
口February \\
March \\
April \\
May \\
June
\end{tabular}

Chart 4.3.2

According to the Chart 4.3.1, the photocopying service has been used most by the undergraduates and it is significantly high in number when compared with the other categories of users. Chart 4.3.2 shows that the books in Clinical Medicine have been the most demanding material to be photocopied during the entire six months 
period where as books in Surgery and Dentistry have been in demand next. Books in Anatomy, Pharmacology, Gynecology, Obstetrics, Biochemistry and Physiology along with the journals have been copied to a certain extent. The survey results suggest that books in these subjects are in demand at the library and it justifies spending some more funds on purchasing the same.

\subsection{Evaluation on the overall affairs of the Library:}

\subsubsection{Collection of data using the questionnaire:}

It was anticipated that $100 \%$ response be received from the samples of undergraduates. However, when administering the questionnaire, due to lesser number of students attending the particular lecture / practical class, it was unable to get the response from $100 \%$ of the targeted users. For example, out of the class of 175 students, only 100 responses were collected. There is also a possibility that all the students may not have returned the questionnaire at the end of the class.

Out of the targeted user population mentioned above, the percentages of responses received are as follows:

$\begin{array}{ll}\text { Medical Students } & -51 \% \\ \text { Dental Students } & -75 \% \\ \text { Academic Staff } & -23 \% \\ \text { Postgraduates } & -33 \%\end{array}$

Representativeness of the respondents in the undergraduate category is very satisfactory while showing poor response in the sample of academic staff.

The responses received from the respondents were analyzed using Excel to produce the Tables 4.2.1-4.2.18, which could be used to make several conclusions on several aspects of the functions of the medical library.

\begin{tabular}{|l|c|c|c|c|}
\hline \multicolumn{1}{|c|}{$\begin{array}{c}\text { Frequency } \\
\text { of use }\end{array}$} & $\begin{array}{c}\text { Medical } \\
\text { students }\end{array}$ & $\begin{array}{c}\text { Dental } \\
\text { students }\end{array}$ & $\begin{array}{c}\text { Academic } \\
\text { staff }\end{array}$ & $\begin{array}{c}\text { Postgraduate } \\
\text { students }\end{array}$ \\
\hline Daily & 13.5 & 14.8 & -- & -- \\
\hline Very often & 30.4 & 23 & 38 & 40 \\
\hline Weekly & 26.6 & 30.7 & 9.5 & 12 \\
\hline Once a month & 4 & 5.9 & 21.4 & 20 \\
\hline Occasionally & 22.9 & 22.4 & 30.9 & 20 \\
\hline
\end{tabular}

Table 4.1.1: Respondents' response as to how often they use the library - as a percentage 
$38 \%$ of the academic staff category uses the library very often while $30.9 \%$ of them use it occasionally. $30.4 \%$ of Medical students and $23 \%$ of Dental students use the library very often. $30.7 \%$ of Dental students and $26.6 \%$ of Medical students use the library weekly.

\begin{tabular}{|l|c|c|c|c|}
\hline \multicolumn{1}{|c|}{$\begin{array}{c}\text { Preferred } \\
\text { days }\end{array}$} & $\begin{array}{c}\text { Medical } \\
\text { students }\end{array}$ & $\begin{array}{c}\text { Dental } \\
\text { students }\end{array}$ & $\begin{array}{c}\text { Academic } \\
\text { staff }\end{array}$ & $\begin{array}{c}\text { Postgraduate } \\
\text { students }\end{array}$ \\
\hline Weekdays & 45.5 & 43 & 85.7 & 40 \\
\hline Weekends & 23.8 & 31.9 & 2.3 & -- \\
\hline Public holidays & 3.2 & 4.1 & -- & -- \\
\hline
\end{tabular}

Table 4.1.2: Respondents' preference of days to come to the library - as a percentage

$85.7 \%$ of Academic staff, $45.5 \%$ of Medical students, $43 \%$ of Dental students and $40 \%$ Postgraduate students preferred to use the library during weekdays. Usage of the library facilities during the weekends is justified by a considerable percentage of undergraduates.

\begin{tabular}{|l|c|c|c|c|}
\hline $\begin{array}{l}\text { Important } \\
\text { library material }\end{array}$ & $\begin{array}{c}\text { Medical } \\
\text { students }\end{array}$ & $\begin{array}{c}\text { Dental } \\
\text { students }\end{array}$ & $\begin{array}{c}\text { Academic } \\
\text { staff }\end{array}$ & $\begin{array}{c}\text { Postgraduate } \\
\text { students }\end{array}$ \\
\hline Students' textbooks & 72 & 90 & 66.7 & 40 \\
\hline Other textbooks & 18.9 & 9.4 & 33.3 & 20 \\
\hline Sri Lanka collection & 10.6 & 1.8 & 28.6 & 40 \\
\hline Current journals & 23.9 & 24.8 & 71.4 & 80 \\
\hline Back issues of journals & 5.8 & 1.8 & 42.8 & 20 \\
\hline CDs ,floppies, videos & 16.4 & 21.8 & 30.9 & 20 \\
\hline Medline-database & 9.4 & 5.3 & 30.9 & 20 \\
\hline
\end{tabular}

Table 4.1.3: The category of library materials the respondents think as important-as a percentage

The majority of the undergraduates consider, students textbooks as the most important library material, while majority of the academic staff and postgraduate students consider current journals as most important. 


\begin{tabular}{|l|c|c|c|c|}
\hline $\begin{array}{l}\text { Library } \\
\text { material }\end{array}$ & $\begin{array}{c}\text { Medical } \\
\text { students }\end{array}$ & $\begin{array}{c}\text { Dental } \\
\text { students }\end{array}$ & $\begin{array}{c}\text { Academic } \\
\text { staff }\end{array}$ & $\begin{array}{c}\text { Postgraduate } \\
\text { students }\end{array}$ \\
\hline $\begin{array}{l}\text { Textbooks from the } \\
\text { reference section }\end{array}$ & 75 & 65.5 & 57 & 80 \\
\hline $\begin{array}{l}\text { Textbooks from the } \\
\text { lending section }\end{array}$ & 31.1 & 54.9 & 21.4 & -- \\
\hline $\begin{array}{l}\text { Textbooks from the } \\
\text { permanent collection }\end{array}$ & 8.6 & 10.6 & 12.3 & 1 \\
\hline Sri Lanka collection & 2.5 & 1.8 & 21.4 & -- \\
\hline Current journals & 10.3 & 3.5 & 71.4 & 60 \\
\hline $\begin{array}{l}\text { Back issues of } \\
\text { journals }\end{array}$ & 3.6 & 0.6 & 57 & 20 \\
\hline Other publications & 1.8 & 1.2 & 12.3 & -- \\
\hline Medline on CD-ROM & 2.2 & 0.6 & 12.3 & -- \\
\hline
\end{tabular}

Table 4.1.4: Respondents' choice for the library material they often use (as a percentage)

Majority of undergraduates have used textbooks from the reference section very often while majority of academic staff have used current journals very often.

\begin{tabular}{|l|c|c|c|c|}
\hline $\begin{array}{l}\text { Fulfilling } \\
\text { the objective }\end{array}$ & $\begin{array}{c}\text { Medical } \\
\text { students }\end{array}$ & $\begin{array}{c}\text { Dental } \\
\text { students }\end{array}$ & $\begin{array}{c}\text { Academic } \\
\text { staff }\end{array}$ & $\begin{array}{c}\text { Postgraduate } \\
\text { students }\end{array}$ \\
\hline Always & 3.4 & 6.4 & 2.4 & 20 \\
\hline Very often & 31.7 & 34.8 & 28.6 & 40 \\
\hline Often & 41 & 32.5 & 47.6 & 20 \\
\hline Sometimes & 18.9 & 14.8 & 19 & - \\
\hline Rarely & 1.8 & 4.7 & -- & \\
\hline
\end{tabular}

Table 4.1.5: Respondents' response about fulfilling their objectives of visits to the Library (as a percentage)

$31.7 \%$ of Medical students, $34.8 \%$ of Dental students and $28.6 \%$ of academic staff could fulfill their objectives very often, while $41 \%$ medical students and $32.5 \%$ Dental students and $47.6 \%$ academic staff responded as 'often' to this query. 


\begin{tabular}{|l|c|c|c|c|}
\hline Reason & $\begin{array}{c}\text { Medical } \\
\text { students }\end{array}$ & $\begin{array}{c}\text { Dental } \\
\text { students }\end{array}$ & $\begin{array}{c}\text { Academic } \\
\text { staff }\end{array}$ & $\begin{array}{c}\text { Postgraduate } \\
\text { students }\end{array}$ \\
\hline $\begin{array}{l}\text { Collection is not } \\
\text { comprehensive enough }\end{array}$ & 15.3 & 15.9 & 35.7 & -- \\
\hline $\begin{array}{l}\text { Non-availability of new } \\
\text { editions and multiple } \\
\text { copies of books }\end{array}$ & 46.6 & 50.1 & 28.6 & -- \\
\hline $\begin{array}{l}\text { Non-availability of } \\
\text { reference materials }\end{array}$ & 13.5 & 10.6 & 28.6 & -- \\
\hline Staff is not supportive & 0.9 & 3 & 21.4 & -- \\
\hline $\begin{array}{l}\text { Non-availability of IT } \\
\text { facilities }\end{array}$ & 12.2 & 5.3 & - & - \\
\hline
\end{tabular}

Table 4.1.6: When respondents' objectives were not fulfilled, the reasons Given (as a percentage)

The reason given by majority of undergraduates for not fulfilling their objectives, was "non-availability of new editions and multiple copies of books". The reason given by the majority of the academic staff was that the collection is not comprehensive enough.

\begin{tabular}{|l|c|c|c|c|}
\hline $\begin{array}{l}\text { Rating on the reference } \\
\text { collection }\end{array}$ & $\begin{array}{c}\text { Medical } \\
\text { students }\end{array}$ & $\begin{array}{c}\text { Dental } \\
\text { students }\end{array}$ & $\begin{array}{c}\text { Academic } \\
\text { staff }\end{array}$ & $\begin{array}{c}\text { Postgraduat } \\
\text { e } \\
\text { students }\end{array}$ \\
\hline Very good & 5.2 & 3.5 & -- & 20 \\
\hline Good & 47.7 & 45.4 & 21.4 & 60 \\
\hline Comprehensive enough & 31.3 & 34.9 & 28.6 & -- \\
\hline Not comprehensive & 12 & 11.8 & 16.7 & - \\
\hline
\end{tabular}

Table 4.1.7: Respondents' rating about the reference collection (as a percentage)

None of the sample population indicates a high esteem of the reference collection. Less than a half of the student population rates it as 'good' while 33\% of them rate it as 'comprehensive enough'. Low esteem by the academic staff about the reference collection reveals that the reference collection needs to be improved. 


\begin{tabular}{|l|c|c|c|c|}
\hline $\begin{array}{l}\text { Rating on the lending } \\
\text { collection }\end{array}$ & $\begin{array}{c}\text { Medical } \\
\text { students }\end{array}$ & $\begin{array}{c}\text { Dental } \\
\text { students }\end{array}$ & $\begin{array}{c}\text { Academic } \\
\text { staff }\end{array}$ & $\begin{array}{c}\text { Postgraduate } \\
\text { students }\end{array}$ \\
\hline Very good & 1.4 & 0.6 & -- & -- \\
\hline Good & 13 & 17.1 & 21.4 & -- \\
\hline Comprehensive enough & 13.5 & 24.2 & 28.6 & 40 \\
\hline Not comprehensive & 68.8 & 32.5 & 38 & 20 \\
\hline
\end{tabular}

Table 4.1.8: Respondents' rating about the lending collection - as a percentage

Majority of the sample population rates the lending collection as 'not comprehensive'. It reveals that regardless of the response by the minor population for 'good' and 'comprehensive enough' the lending collection needs improvement.

\begin{tabular}{|lc|c|c|c|c|}
\hline $\begin{array}{l}\text { Rating on the SL } \\
\text { collection }\end{array}$ & $\begin{array}{c}\text { Medical } \\
\text { students }\end{array}$ & $\begin{array}{c}\text { Dental } \\
\text { students }\end{array}$ & $\begin{array}{c}\text { Academic } \\
\text { staff }\end{array}$ & $\begin{array}{c}\text { Postgraduate } \\
\text { students }\end{array}$ \\
\hline Very good & 1 & 0.7 & -- & -- & -- \\
\hline Good & 2 & 13.3 & 19.5 & 30.9 & 20 \\
\hline Comprehensive enough 3 & 21.1 & 30.1 & 30.9 & 60 \\
\hline Not comprehensive & 4 & 21.7 & 24.2 & 21.4 & -- \\
\hline
\end{tabular}

Table 4.1.9: Respondents' rating about the Sri Lanka Collection - as a percentage Undergraduates and academic staff rate the SL collection at 2-4 above, while postgraduates have a high esteem of $60 \%$ for 'comprehensive enough'. It reveals that the academic staff has been benefited by this collection, still requiring improvement.

\begin{tabular}{|c|c|c|c|c|}
\hline Rating on the PR collection & $\begin{array}{l}\text { Medical } \\
\text { students }\end{array}$ & $\begin{array}{c}\text { Dental } \\
\text { students }\end{array}$ & $\begin{array}{c}\text { Academic } \\
\text { staff }\end{array}$ & $\begin{array}{c}\text { Postgraduate } \\
\text { students }\end{array}$ \\
\hline Very good & 2 & 1.8 & -- & -- \\
\hline Good & 20.3 & 32.5 & 33.3 & 40 \\
\hline Comprehensive enough & 20.1 & 26 & 21.4 & -- \\
\hline Not comprehensive & 22.9 & 30.7 & 26.1 & $-m$ \\
\hline
\end{tabular}

Table 4.1.10 Respondent's rating about the Permanent Reference collection as a percentage

Rating of the undergraduates and academic staff is equally distributed at 2-4 above to a certain extent, which reveals that further improvement is required. 
Materials to be added

Students textbooks

Reference books

Colour atlases

Picture tests books

M.C.Q. books

CD- ROMs of books

Journals (print)

Journals on line

\begin{tabular}{c|c|c|c|}
$\begin{array}{c}\text { Medical } \\
\text { students }\end{array}$ & $\begin{array}{c}\text { Dental } \\
\text { students }\end{array}$ & $\begin{array}{c}\text { Academic } \\
\text { staff }\end{array}$ & $\begin{array}{c}\text { Postgraduate } \\
\text { students }\end{array}$ \\
58.5 & 67.8 & 50 & 20 \\
39.4 & 59.6 & 71.4 & 60 \\
39 & 37.2 & 26.2 & -- \\
40 & 27.1 & 23.8 & -- \\
18.2 & 7.1 & 21.4 & 20 \\
16.9 & 19.5 & 28.6 & -- \\
15.3 & 16.5 & 59.5 & 60 \\
\hline
\end{tabular}

Table 4.1.11: Respondent's suggestions about the materials to be added more to the Collection- as a percentage

According to Table 4.2.11, Student's textbooks, reference books, print journals and online- journals were the materials to be added more to the collection as suggested by the majority of the users.

\begin{tabular}{|l|c|c|c|c|}
\hline \multicolumn{1}{|c|}{ Suggestion } & $\begin{array}{c}\text { Medical } \\
\text { students }\end{array}$ & $\begin{array}{c}\text { Dental } \\
\text { students }\end{array}$ & $\begin{array}{c}\text { Academic } \\
\text { staff }\end{array}$ & $\begin{array}{c}\text { Postgraduate } \\
\text { students }\end{array}$ \\
\hline $\begin{array}{l}\text { Improve lending } \\
\text { Collection }\end{array}$ & 68.9 & 77.9 & 50 & 20 \\
\hline $\begin{array}{l}\text { Improve reference } \\
\text { collection }\end{array}$ & 49.5 & 52.5 & 55 & 20 \\
\hline $\begin{array}{l}\text { Improve permanent } \\
\text { ref.- collection }\end{array}$ & 17.8 & 18.9 & 26.2 & 40 \\
\hline $\begin{array}{l}\text { Improve Sri Lanka } \\
\text { collection }\end{array}$ & 10.6 & 5.3 & 26.2 & 20 \\
\hline $\begin{array}{l}\text { Improve Journal } \\
\text { collection }\end{array}$ & 17.5 & 10 & 78.5 & 20 \\
\hline Improve IT facilities & 20.2 & 28.9 & 47.6 & 60 \\
\hline
\end{tabular}

Table 4.1.12: Respondent's suggestion for improvement in the collection as a percentage

Majority of the users suggests improvement in the lending collection, reference collection, journal collection and in IT facilities. Undergraduates have a strong appeal for improvement in the lending collection while the academic staff has a strong appeal for improvement in the journal collection. 


\begin{tabular}{|l|c|c|c|c|c|}
\hline $\begin{array}{l}\text { Rating on } \\
\text { journals }\end{array}$ & Response & $\begin{array}{c}\text { Medical } \\
\text { students }\end{array}$ & $\begin{array}{c}\text { Dental } \\
\text { students }\end{array}$ & $\begin{array}{c}\text { Academic } \\
\text { staff }\end{array}$ & $\begin{array}{c}\text { Postgraduate } \\
\text { students }\end{array}$ \\
\hline availability & satisfied & 22.7 & 40.7 & 28.6 & 80 \\
\hline & not satisfied & 27.9 & 34.8 & 66.6 & 20 \\
\hline Accessibility & easy & 22.3 & 24.3 & 30.9 & 40 \\
\hline & not easy & 19.1 & 25.4 & 61.9 & 20 \\
\hline $\begin{array}{l}\text { Subject } \\
\text { coverage }\end{array}$ & good & 17.8 & 28.3 & 47.6 & 20 \\
\hline & poor & 30.2 & 34.9 & 38 & 20 \\
\hline Currency & good & 17.5 & 21.8 & 35.7 & 20 \\
\hline & poor & 16.6 & 22.4 & 30.9 & 20 \\
\hline
\end{tabular}

Table 4.1 13 Respondent's rating about the journals collction - as a percentage About the journal collection, a higher percentage of academic staff is not satisfied about the availability and said that accessibility is not easy. It suggests that the journal collection has to be improved. The low response rate of the student population on this question reveals that the usage of journals by undergraduates has been at a low rate.

\begin{tabular}{|l|c|c|c|c|}
\hline \multicolumn{1}{|c|}{ Frequency of } & Medical \\
journal usage & $\begin{array}{c}\text { Dental } \\
\text { students }\end{array}$ & $\begin{array}{c}\text { Academic } \\
\text { students } \\
\text { staff }\end{array}$ & $\begin{array}{c}\text { Postgraduate } \\
\text { students }\end{array}$ \\
Waily & 1.08 & 1.2 & -- & 20 \\
Oncekly & 10.3 & 8.9 & 50 & 40 \\
Occasionally & 7.6 & 7.1 & 23.8 & 20 \\
Unlikely & 36.2 & 44.2 & 38 & 20 \\
\hline
\end{tabular}

Table 4.1 14 Respondent's response about how often they use the journals - as a percentage

According to Table 4.2.14, 50\% of the academic staff uses journals weekly while $36.2 \%$ of Medical and $44.2 \%$ Dental students use journals occasionally. Rest of the $50 \%$ of the academic staff uses the journals once a month or occasionally. Most of the postgraduates use the journals weekly.

Type of journal used

Current journals

Back issues of journals

Medline on CD- ROM

Medical
students
33.3
8.3
6.4

Dental
students
49.6
9.4
3.5

Academic
staff
54.7
16.7
21.4

Table 4.1 15 Respondent's response about what they used most out of journals - as a percentage 
Data in the above table reveals that all four samples of the population have used current journals most.

\begin{tabular}{|l|c|c|c|c|}
\hline $\begin{array}{l}\text { Opinion on the library } \\
\text { staff }\end{array}$ & $\begin{array}{c}\text { Medical } \\
\text { students }\end{array}$ & $\begin{array}{c}\text { Dental } \\
\text { students }\end{array}$ & $\begin{array}{c}\text { Academic } \\
\text { staff }\end{array}$ & $\begin{array}{c}\text { Postgraduate } \\
\text { students }\end{array}$ \\
\hline Very supportive & 45.9 & 36 & 69 & 60 \\
\hline Not supportive & 1.8 & 3.5 & -- & -- \\
\hline Competent enough & 26.1 & 25.4 & 14.3 & 20 \\
\hline Should be improved & 20 & 17.1 & 11.9 & - \\
\hline
\end{tabular}

Table 4.1.16 Respondent's opinion about the library staff- as a percentage

A higher percentage of users in each category gauged the library staff as very supportive and competent enough while a small percentage suggested for improvements.

\begin{tabular}{|l|l|c|c|c|c|}
\hline $\begin{array}{l}\text { Physical } \\
\text { arrangement }\end{array}$ & Response & $\begin{array}{c}\text { Medical } \\
\text { students }\end{array}$ & $\begin{array}{c}\text { Dental } \\
\text { students }\end{array}$ & $\begin{array}{c}\text { Academic } \\
\text { staff }\end{array}$ & $\begin{array}{c}\text { Postgraduate } \\
\text { students }\end{array}$ \\
\hline $\begin{array}{l}\text { Seating } \\
\text { arrangements }\end{array}$ & satisfied & 56 & 59 & 59.5 & 80 \\
\hline & not satisfied & 32.6 & 28.3 & 19 & 20 \\
\hline No. of seats & enough & 56.7 & 67.9 & 69 & 100 \\
\hline & not enough & 30.7 & 17.7 & 12.3 & -- \\
\hline Appearance & satisfied & 4 & 56.6 & 64.3 & 60 \\
\hline & not satisfied & 21.1 & 14.8 & 9.5 & -- \\
\hline Ventilation & satisfied & 45.4 & 54.9 & 59.5 & 40 \\
\hline & not satisfied & 41.9 & 31.9 & 23.8 & 40 \\
\hline $\begin{array}{l}\text { Arrangement of } \\
\text { books and } \\
\text { journals }\end{array}$ & satisfied & 43.7 & 56.7 & 50 & 60 \\
\hline & not satisfied & 34.2 & 31.9 & 28.6 & 40 \\
\hline $\begin{array}{l}\text { Disturbances } \\
\text { inside the library }\end{array}$ & rare & 46.1 & 46 & 57 & 60 \\
\hline & often & 30.9 & 34.8 & 23.8 & 20 \\
\hline & always & 5 & -- & -- & -- \\
\hline
\end{tabular}

Table 4.1.17 Respondent's response about the physical arrangement in the library - as a percentage 
Variations are shown in the responses regarding each aspect of the physical arrangement. However the overall opinion given by the table 4.2.17 is that the user population is satisfied with the present conditions except for a few. Ventilation and arrangement of books and journals need to be improved.

\begin{tabular}{|l|c|c|c|c|}
\hline Opening hours & $\begin{array}{c}\text { Medical } \\
\text { students }\end{array}$ & $\begin{array}{c}\text { Dental } \\
\text { students }\end{array}$ & $\begin{array}{c}\text { Academic } \\
\text { staff }\end{array}$ & $\begin{array}{c}\text { Postgraduate } \\
\text { students }\end{array}$ \\
\hline Satisfied with the current hours & 38.7 & 29.5 & 65.5 & 50.5 \\
\hline $\begin{array}{l}\text { It has to be extended till } \\
\text { 10.00p.m. }\end{array}$ & 35.3 & 19.5 & 8.0 & 20.8 \\
\hline $\begin{array}{l}\text { It has to be extended till 12 } \\
\text { midnight }\end{array}$ & 13.1 & 11.2 & -- & -- \\
\hline $\begin{array}{l}\text { From 7.30 a.m .to 6.30p.m.is } \\
\text { sufficient }\end{array}$ & 3.1 & 6.4 & -- & -- \\
\hline
\end{tabular}

\section{Table 4.1 18: Respondent's response about the opening hours - as a percentage}

It reveals that the current opening hours are appropriate for more than half of the academic staff population while it is same for $50 \%$ of postgraduate students. Equal percentages of student population suggest current hours and extended hours till 10.00p.m.

The results of the survey facilitate the library administration to evaluate the various aspects of the management of the library functions and to judge the extent of the improvements needed. It also provides us with guidelines for proper management of the limited resources and funds.

\section{References:}

Hernon, P., \& McClure,C. (1990) Evaluation and library decision making. Norwood, NJ

Van House, N.; Weil,N. \& McClure, C. (1990) Measuring academic library performance : a practical approach Chicago : American Library Association

Hernon, P. \& Altman E. (1998) Assessing service quality : satisfying the expectations of library customers. Chicago: American Library Assosciation. 
Hernon, P. \& Whitman, J. (2001) Delivering satisfaction and service quality: a customer-based approach for libraries. Chicago: American Library Assosciation.

Hiller, Steve (2001) Assessing user needs, satisfaction and Library performance at the University of Washington Libraries.49(4), p.605-23. 